\title{
Good Governance, Democracy and Leadership styles in Africa
}

\author{
Chikerema Arthur, Sithole Angeline, Chakunda Vincent and Matsika Kudzai \\ Midlands State University Faculty of Social Sciences Local Governance Studies Department P. Bag 9055 \\ Gweru Zimbabwe
}

\begin{abstract}
Issues of constitutionalism, good governance and democracy are determined by the type of leadership in a country and/or continent. Despite colonial legacy, leadership in Africa has struggled to promote pro-people policies that accommodate the needs of the populace. Leadership deficiency is a cause for concern in African countries in terms of progressive and visionary leadership. Perspectives on political leadership in Africa vary from the "criminalisation" of the state to political leadership as "dispensing patrimony", the "recycling "of elites and the use of state power and resources to consolidate political and economic power as stated by Van Wyk (2007). African states and their leaders have exploited and monopolized internal sovereignty to mean absolute power, persornalisation of state-like services and have monopoly of and over organised violence.

This paper attempt to review and analyze the type and styles of political leadership in Africa in an effort to promote democracy and good governance. Leaders play a pivotal role in political agenda setting, the distribution of resources and political actions. The contemporary state in Africa is a remnant of a colonially imposed system. At the time of independence, elites attempted to transform this but only succeeded in entrenching their interests. This paper therefore seeks to unpakage why African countries are no better than they were under colonial rule. Of what value then is the hard won independence that African countries commemorate on a yearly basis? African politicians need to provide good leadership qualities so as to consolidate democracy and good governance
\end{abstract}

KeyWords: Democracy, Democratic Consolidation Leadership, leader, Governance and Human Rights

\section{Introduction}

Nearly everyone today professes to be a democrat. Political regimes of all kinds throughout the world describe themselves as democracies, yet what these regimes say and do is often substantially different from one another. Political leaders that brought independence in Africa such as Mugabe and other departed Nationalistic leaders boosted of being patriots and democrats in their own right. They have rhetorically manipulated their subjects by their emphasis on issues of sovereignty, independence, self determination and patriotism only for their own interest. They talk populist while they are capitalist. There is extensive personalization of power that discourages the growth of wider forms of trust and reciprocity Venter (2011) for example Kamuzu Banda of Malawi during his reign had the audacity to ask why there is political opposition in Malawi when God has no opposition in heaven. In Africa there widespread abuse of fundamental human rights by errant rulers, and human rights abuses cause many citizens to withdraw from politics, or evade rather than engage political authorities Ananim et al (1990). Generally, they have been reluctant to speak out for fear of being jailed or mistreated and, instead, have increasingly exercised the option "to vote with their feet" in order to escape repressive political persecution even if the constitutions guarantees freedom of expression. Africa is home to unelected and unaccountable government that manifest themselves in a reluctance to decentralise or delegate authority and a tendency to curb any independent political activity outside an institutional network controlled by the ruling party, Chabal (1999). This lead to a situation in which the apparatus of the state primarily becomes the means for the elite to acquire wealth, rather than serving as a corrective mechanism to promote social justice and sustainable economic development. This has led to widespread and even endemic corruption. The continent needs to answer Ugandan President's questio in his published article, what is Africa 's problem? , but for the purposes of this paper, leadership is the precise answer. Africa needs leaders that respect and follow the provisions of their constitutions and who cultivate a culture of constitutionalism, democracy and good governance in the continent, since political leaders are the primary holders, controllers and distributors of power and resources in a particular institution (i.e. institutional power) and/or territory (i.e. geo-political power).

\section{Conceptualization of terms}

The term "democracy"' means different things to different people. Indeed, there is a wide range of perspectives as to the meaning and content of democracy as well as to the conditions of its realization; all of which vary depending on the philosophical, ideological, political, cultural, social, and economic perspectives. 
This range of perceptions goes from the higher conceptual plane as expressed, for example, by the great thinkers of western civilization and by other great non-western political philosophers, to the practical means of application as expressed by contemporary experts.

However, in almost all circumstances, democracy involves social justice, governmental accountability, and human freedoms, Venter (2011). Certainly, democracy involves the procedural minimum of contestation for political office and policy choices, of popular participation in elections and other elements of political decisionmaking, and the accountability of elected public officials under the rule of law. All this must take place within a culture in which fundamental human rights and political freedoms are guaranteed, Keller (1995). However, democracy should be made, and should be seen to work, particularly where there is "inadequate commitment to multi party democracy and politics among leaders and politicians ... [who] talk democracy, but use undemocratic means to remain in power". Leaders in Africa should walk the talk and practice what they preach. All this rot has flourished because "Africans have no shared value standards or binding rules and principles. For some of them, democracy is a foreign concept, Marume (1998). The populace has been used as pawns by politicians who manipulate them for personal aggrandizement.

\section{Good Governance:}

Governance is the practice of good government Bratton and Rothchid (1997) and it remains, essentially, a fragile process that depends on "the restraint of the ruler" and "the tolerance of the ruled" Barkan (1992). The concept of governance refers to the task of running a government (or any other appropriate entity, like a business) and, since the late 1980s, the crisis on the African continent has been identified as one of governance, Worldbank (1989). This has been supported by the Former UN Secretary General Kofi Annan who argues that for Africa to prosper, "good governance, the rule of law, and systems of accountability are essential to ensure that resources are subject to public scrutiny and used effectively and efficiently. He further argued that for this, the continent needs "determined political leadership to set and drive plans for equitable growth and poverty reduction .... Good, even visionary agendas have been formulated by African leaders and policy-makers in every field .... [But] technical management and institutional capacity are vital if policies are to be implemented .... [However, the lack of] political will ... is the issue. In many African countries the fundamental principles of democratic governance are consistently, deliberately, and openly being violated, Venter (2011) . Therefore, Africa needs good leadership to consolidate democracy and good governance

\section{Literature Review}

\section{Political Leadership in Africa}

Based on empirical observations since the hard - won political independence from colonial Europe, the type of political leadership has become one of Africa's sources of problems.

Some scientists and critics such as Naomi Chazan, Nzongola Antalanja and Paul Viotti observe that the lamentably slow pace of African economic development, mirrored by rampant hunger, massive unemployment, disease, poverty and deprivation are quite often blamed on imperialism and colonialism, Hartmann (1983). This historical aspect is true because after the Berlin Conference of 1884 - 85, Africa was partitioned by the Portuguese, Italian, Spanish, French, British, German, Belgian and Dutch colonialists and imperialists whose major interest was to exploit the continent's rich mineral resources, the fertile soils and an illiterate community that provided unquestioningly cheap labour then Walter (-1981--). Although the age of European colonization is now over, the signs of those times are still visibly clear for example Africans had little time to prepare for independence and at independence the incoming elite inherited alien structures. It inherited state structures developed through coercive mechanisms and centralized political and economic controls such as the army, police and the bureaucracy. This resulted in the establishment of a political culture based on ethnicity and authoritarian patterns of governance. Controlling the state and its resources became the primary purpose of political contestation. It is equally true that: Africa is, however, generally underdeveloped, where political violence, intolerance, repression and dictatorships are common. Africa is also a continent of great potential with magnificent environmental heritage and the possibility of significant improvements. Perhaps due to unfamiliarity with modern governmental machinery, unaccustomed to parliamentary democratic debate, and the process of multiparty constitutional systems, many African states have too quickly abandoned democracy. In some cases this is due to the total dominance of a single political party, which outlaws opposition parties, but is more normally produced by a military coup. Nearly all African states have experienced political violence and dictatorship at some stage during their short period of independence. Many are still ruled without democracy. There have been numerous accusations of human rights violations in these states. In some cases government forces have been responsible for horrific attacks and massacres of innocent and defenseless citizens - cases of rape have been reported for example the Genocide in Rwanda that killed 800000 defenseless civilians and the Gukurahundi Massacre in Zimbabwe between 1983-87. Africa is undoubtedly a beautiful and potentially wealthy continent, but its endemic problems and recurring political violence have locked it into a vicious cycle 
of poverty which will prove difficult to break. It is difficult for the losing political parties to concede defeat after elections and to hand over power to incoming victors, This has resulted in what is termed "negotiated democracy" where losers seek political power through negotiations, compromise and intimidation, which resulted in the flavour of the continent of "coalition government", thus doing violence to democracy Marume, (1988) for example the case of 2008 presidential elections results in Zimbabwe which took two weeks to be announced and the protracted 2007 Kenyan elections which resulted in ethnic clashes which claimed more than 1000 lives. There is something peculiar about election defeat in Africa.

\section{Political Power, Leadership and Governance}

African leaders still blame colonial legacy for the problems bedeviling Africa at the moment. After 50 years of independence Africa still point a finger to the west, but how clean are African Leaders' hands and this is the big question that need to be answered. Thus, besides imperialism and colonialism, dictatorial rule by Africans themselves, characterized by the injudicious plunder of national resources, absence of the rule of law, rampant corruption, repressive legislation against the media for example the Access to Information and Protection of Privacy Act (AIPPA) and Public Order and Security Act (POSA) in Zimbabwe which limit the freedom of association and expression and the judiciary; brutal suppression of the opposition parties and dissenting voices retards development of individual African states and Africa itself, Marume (1988). In Swaziland, King Mswati outlawed opposition parties, power and authority revolves around him.

Instead of constructively consolidating their hard won political independences, many African leaders have quickly become tyrants, dictators, and one party state ruler. For example the de facto one party state by ZANU(PF) between 1985 to 1995 . Many opposition leaders has been charged for treason notable Tsvangirai of Zimbabwe, Uganda and DRC opposition leaders have been arrested for challenging the sitting presidents. This is true of North Africa which is Afro-Arabic, and black Africa itself - west, east, central and southern Africa and this type of leadership has lead to the Arab revolution in the recent years. Africa, therefore, has a problem, Marume (1988).

Guided by some foreign ideologies, for example, Marxism - Leninism, communism, socialism, humanism, Ujamaa, most new African leaders have descended quite quickly on opposition political parties, civic societies, individuals, universities and colleges like a tornado, arresting, detaining, torturing, kidnapping and killing of Africans by Africans on the nefarious pretexts of protecting national sovereignty, Hartman (1983)

African leaders have introduced repressive legislation much worse than that of colonial legislation, which literally robs the media, the judiciary, and civic society of professional and civilized independence, Hartmann (1983) for example POSA and AIPPA in Zimbabwe. The army, police and secret services have become subservient institutions and members of the ruling political parties and turn a blind eye to the notorious transgressions by anyone from the establishment, Hartmann (1983). The consequence is predictable: thugocracy, anarchy, rape, murder, disappearances, massive hunger, disease and poverty among the masses who are not allowed to question any decision made by the ruling elite for example Kenya and Zimbabwe have resembled a state of nature where life is nasty, brutal and short, the survival of the fittest scenario which degenerated to a state of war because of intolerance and politics of exclusion between rival parties. African history is littered with cases of misrule, dictators and tyrants as well as instances of inappropriate political policies.

\section{Power and Resources in Africa}

It is also observed that some of Africa's remaining absolute monarchies, who have come to power at the deaths of their fathers for example King Mswati and the late Gaddaffi, have amassed a lot of money, making themselves some of the richest leaders in the world. There is evidence that some of them lead opulent lifestyles such as Mobutu Seseseko of The Democratic Republic of Congo, yet their people, whom they rule with iron fists, are among the poorest in the world and cannot afford to put food on the table for their families due to antipeople policies crafted by the same leaders who claim to be populist during the day and yet are capitalist during the night. When they are deposed or when they die in office, most of them leave a legacy of economic ruin, huge foreign debt, high inflation, crumbling industrial sector, high unemployment at times tribal divisions, and misery among the people Marume (1988) for example Mobutu Seseseko was wealthy but the generality of Congolese were wallowing in abject poverty. What is even particularly striking is that some of these dictators want their wives, sons and daughters to succeed them.

\section{Conclusion}

When social scientists speak of African plunder, poverty, hunger, unemployment and deprivation there is no way one cannot point a finger at the continent's dictators and their misrule. It is most inconsistent, inconceivable, tragic, despicable and ironic that African liberators adopt some of the repressive legislation that was used against them by the colonialists during the struggle for political independence. In the end there is a 
scenario in which African nationalist leaders removing colonial rule only to replace it with brutal, murderous, repressive African tyranny in a modern African country and in a contemporary African continent"

\section{References}

[1]. An-na'im, A.A. and Deng, F.M., 1990. Human rights in Africa: Cross-cultural perspectives, Brookings Institution, Washington, D.C.

[2]. Barkan, J. D., 1992. The rise and fall of a governance realm in Kenya. In Goran Hyden and Michael Bratton, (Editors) Governance and Politics in Africa, Lynne Rienner Publishers, Colorado.

[3]. Bratton, M. and Rothchild, D., 1992. The institutional bases of governance in Africa. In Hyden Goran and Bratton Michael. (Editors) Governance and politics in Africa, Lynne Rienner Publishers, Boulder Colorado.

[4]. Chabal, P. and Daloz, J., 1999. Africa Works: Disorder as Political Instrument (African Issues), James Currey Publishers, New York.

[5]. Hartmann, F.H., 1983. The relations of Nations, MacMillan Company, New York.

[6]. Held, D., 2006. Models of democracy, $3^{\text {rd }}$ edition, Stanford University Press, California.

[7]. Hirschman, Albert O., 1970. Exit, voice and loyalty: Responses to decline in firms, organizations and states, Harvard University Press: Cambridge, Massachusetts.

[8]. Hyden, G. and Bratton, M., 1992. Governance and the study of politics. In Hyden, Goran and Bratton, Michael. (Editors) Governance and politics in Africa, Lynne Rienner Publishers, Boulder (Colorado).

[9]. Keller, E. J., 1995. Liberalisation, Democratisation and Democracy in Africa, Comparative perspectives, Africa Insight, 25(4) pp 224-230.

[10]. Marume, S.B.M., 1988. Advanced study of methods in, approaches to, theories and value foundations of public administration. Unpubl. Ph.D. Thesis, California University for Advanced Studies.

[11]. Rodney, W., 1981. How Europe Underdeveloped Africa, Harvard University Press, Washington D.C.

[12]. Summary of World Broadcasts., 2000. SADC MPs call for commitment to pluralism, democratic practices. 17 October. Johannesburg, South African Press Association (SAPA), p. AL/3973 A/4

[13]. World Bank., 1989. Sub-Saharan Africa: From crisis to sustainable growth, World Bank, Washington, D.C.

[14]. Venter.D, 2011. The Imperatives of Democracy, Governance and Leadership in the Fight against Corruption in Africa: A South African Perspective, Paper presented at the International Conference on "Democratic Governance: Challenges in Africa and Asia", organised by the Association for Middle Eastern Public Policy and Administration (AMEPPA). 